\title{
周波数特性に基づく流体回路系の過渡応答計算法 ${ }^{+}$
}

\author{
吉岡宗 之*・森川敬 信* \\ A Method of Transient Response Calculation for the Fluid Circuit Systems \\ on the Basis of Frequency Characteristics \\ Muneyuki YoshiokA* and Yoshinobu MorIKawA*
}

\section{1. はじめに}

管路系の過渡応答計算に際しては，周波数領域でそ の有用性が広く検証されているBrownの管路モデル1 さえむ，未だ十分使いてなす至っていない，そてで 本報では，まず最初に線形で安定な系の過渡応答を周 波数特性に基づいて計算する方法を提示し，そのうえ でこの手法を管路系に適用する場合の有用性をBrown のモデルに即して明らかにする，また，Johnson らの 近似的な過渡応答計算法 ${ }^{22}$ と本報の方法との関連性を あ示す.

\section{2. 過渡応答計算法}

線形系を考え, $s$ 領域 ( $s$ : Laplace 演算子) に扣け る入力を $P_{i}(s)$, 伝達関数を $G(s)$, 出力を $P_{0}(s)$ とす るとき, $P_{0}(s)=P_{i}(s) G(s)$ であり, $t$ 領域 $(t$ : 時間) に扒ける出力 $p_{0}(t)$ は, $s=b+j \omega(b=$ const. $>0, j$ $=V-1, \omega$ : 角周波数) を用いて次式で表わせる.

$$
p_{0}(t)=\frac{1}{2 \pi j} \int_{b-j \infty}^{b+j \infty} P_{0}(s) e^{s t} d s
$$

ただし，正の定数 $b$ は $P_{0}(s)$ のすべての極が積分路の 左側位位置するように選ぶ必要がある.

さて, $P_{0}(s)$ の極が容易に求まらない場合, (1) 式 を数值積分することが必要优なる。そこでいま $s=b$ $+j \omega, d s=j d \omega$ を用いて(1) 式を書き換えると,

$$
\begin{aligned}
p_{0}(t)= & \frac{e^{b t}}{2 \pi} \int_{0}^{\infty}\left\{P_{0}(b+j \omega) e^{j \omega t}\right. \\
& \left.+P_{0}(b-j \omega) e^{-j \omega t}\right\} d \omega
\end{aligned}
$$

之なる. したがって原理的には, 定数 $b$ を与えて $P_{0}$ $(b \pm j \omega)$ を計算し， $\omega$ について数值積分を実行するて こで，任意の線形系の過渡応答が計算できる ${ }^{3}$. しか し，後述する管路系のように $P_{0}(b \pm j \omega)$ の計算が非 常に面倒で，かつ積分範囲を広く取る必要のある場合 には，乙の方法あ実用性にそしい，そこでつぎに，条

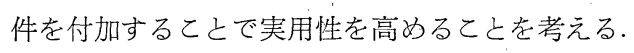

$\dagger$ 日本機械学会関西支部第 53 期定期総会講演会で発表（昭 $53 \cdot 3)$

* 大阪大学工学部 吹田市大字山田上

(Received November 8, 1978) まず，(a)系は安定であり，(b)入力 $p_{i}(t)$ の最終 值恃有限確定であるものと仮定する，乙の之き，原点 の近傍で積分路を半円周 $s=b+r e^{j \theta}(r>0,-\pi / 2 \leqq \theta$ $\leqq \pi / 2)$ に変更すれば， $b \rightarrow+0, r \rightarrow+0$ とするととが 可能になり, (1)式より出力 $p_{0}(t)$ はつぎのように表 わせる。

$$
\begin{aligned}
& p_{0}(t)=\frac{1}{2 \pi} \lim _{r \rightarrow+0}\left\{\int_{-\pi / 2}^{\pi / 2} P_{0}\left(r e^{j \epsilon}\right) e^{r t e^{j \theta}} r e^{j \theta} d \theta\right. \\
& \left.+\int_{-\infty}^{-r} P_{0}(j \omega) e^{j \omega t} d \omega+\int_{r}^{\infty} P_{0}(j \omega) e^{j \omega t} d \omega\right\} \\
& =\frac{P(0)}{2}+\frac{1}{2 \pi} \int_{0}^{\infty}\left\{P_{0}(j \omega) e^{j \omega t}+P_{0}(-j \omega) e^{-j \omega t}\right\} d \omega \\
& P(0)=\lim _{s \rightarrow 0} s P(s)
\end{aligned}
$$

ここで $P(0) / 2$ は半円周上の積分值であり, 出力の最 終值を $p_{0}(\infty)$ とするとき $p_{0}(\infty)=P(0)$ である.

いま, 入力として (a) 単位ステップ, (b) Terminated-ramp（飽和するまでの時間 $\tau_{1}$, 飽和值 1 ), (c) 単一矩形パルス (パルス幅 $\tau_{2}$, 高さ1) を考えるあの とすれば，（3)式よりそれぞれつぎのようになる.

(a) 単位ステップ応答

$$
\begin{aligned}
& p_{0}(t)=\frac{G(0)}{2}+\int_{0}^{\infty} \frac{|G(j \omega)|}{\pi \omega} \sin (\omega t+\varphi) d \omega \\
& \varphi=\arg G(j \omega)
\end{aligned}
$$

(b) Terminated-ramp 応答

$$
\begin{aligned}
p_{0}(t)= & \frac{P(0)}{2}+\int_{0}^{\infty} \frac{|G(j \omega)|}{\pi \tau_{1} \omega^{2}}\left\{\cos \left(\omega t+\varphi-\omega \tau_{1}\right)\right. \\
& -\cos (\omega t+\varphi)\} d \omega
\end{aligned}
$$

(c) 単一矩形パルス応答

$$
\begin{aligned}
p_{0}(t)= & \int_{0}^{\infty} \frac{|G(j \omega)|}{\pi \omega}\{\sin (\omega t+\varphi) \\
& \left.-\sin \left(\omega t+\varphi-\omega \tau_{2}\right)\right\} d \omega
\end{aligned}
$$

なお， $N>0$ とするとき，入力 $p_{i}(t)$ が条件式

$$
\int_{0}^{\infty}\left|p_{i}(t)\right| d t=N<\infty
$$

を満たすなら, 周知のとおり過渡応答は Fourier 変換 法によっても求まり，ての場合 Laplace 逆変換に沶い ては上述の半円周上の積分值が 0 になる. (c)がこの 例汇当たる.

さて, 以上の過渡応答計算法は, 仮定した要件を満 
たすかぎり適用対象を限定する必要はないが，管路系 への適用に扔いて特に有用であり，元来そのために考 案したものである.したがって，その考察の過程を明 らかにすることは計算法の特徽书よびそてに至る必然 性を明確にすることに通じるので，つぎにそれを示す。

\section{3. 管路系への適用の有用性}

管路を含む系では，伝達関数 $G(s)$ の中に管路の伝 播定数 $\gamma(s)$, 特性インピーダンス $Z_{c}(s)$ を含み, 乙れ らは一般に $s$ の複雑な関数である。たとえば Brown のモデル ${ }^{1)}$ では $\gamma(s)=V \overline{Z(s) Y(s)}, Z_{c}(s)=V \overline{Z(s) / Y(s),}$ ただし

$$
\begin{aligned}
& Z(s)=s L\left\{1-\frac{2 J_{1}\left(j a \sqrt{\frac{s}{\nu}}\right)}{j a \sqrt{\frac{s}{\nu}} J_{0}\left(j a \sqrt{\frac{s}{\nu}}\right)}\right\}^{-1} \\
& Y(s)=s C\left\{1+\frac{2(\kappa-1) J_{1}\left(j a \sqrt{\frac{\sigma s}{\nu}}\right)}{j a \sqrt{\frac{\sigma s}{\nu}} J_{0}\left(j a \sqrt{\frac{\sigma s}{\nu}}\right)}\right\}
\end{aligned}
$$

$\left(a\right.$ : 管半径, $C=\pi a^{2} / \rho c^{2}, c$ : 音速, $J_{0} ; J_{1}:$ Bessel 関数, $L=\rho / \pi a^{2}, \kappa$ : 比熱比（液体の場合 $\kappa=1$ ), $\nu$ : 動粘性係数, $\rho$ : 密度, $\sigma$ : Prandt1 数) で与えられ る. したがって, $s \doteq b+j \omega$ と执いて $\gamma, Z_{c}$ を求めよ うとすれば，任意偏角に対する $J_{0}, J_{1}$ を計算するとと が必要になる．また $r(b+j \omega), Z_{c}(b+j \omega)$ などは多 価関数であり，数值計算の過程で物理的に意味のある 值を選び出す必要がある。一方， $s=j \omega$ とすれば $J_{0}$, $J_{1}$ の偏角は $\arg j \vee \bar{j}$ となり，乙のとき Bessel 関数 は Kelvin 関数を用いて

$J_{n}\left(x e^{3 \pi j / 4}\right)=e^{n \pi j} J_{n}\left(x e^{-\pi j / 4}\right)=\operatorname{ber}_{n} x+j$ bei $_{n} x$

と表わせる，そのうえ $r(j \omega), Z_{c}(j \omega)$ の多価性注解析 的に処理できる。したがって $\gamma(j \omega), Z_{c}(j \omega)$ の計算は $\gamma(b+j \omega), Z_{c}(b+j \omega)$ に比べてはるか㳊簡単になる。 ゆえに管路系の過渡応答計算化打いては，(3)式に上 る方法は実用に耐え有用である。なお，乙の計算法を 容量で終端された空気圧伝送系のステップ応答に適用 し，実験と屯比較して良好な結果を得ており ${ }^{4)}$ ，詳細 は改めて公表する予定である。

\section{Johnson らの近似法との関連}

ステップ応答を矩形パルス列に対する応答で近似す る方法が Johnson らによって提案され2)，空気圧伝送 系のステップ応答の計算にも Katz らによって利用さ れている5 ${ }^{5,6)}$. そてでどてでは，Johnson らの方法で 求まる結果が (4)式の近似形であるととを示す。

矩形パルス列の周期を $T\left(\omega_{0}=2 \pi / T\right), 0<t<T / 2$ で $p_{i}(t)=1, \quad T / 2<t<T$ で $p_{i}(t)=0$ となるよう座標軸 の基点およびパルス幅を定めるとき， $p_{i}(t)$ は

$$
p_{i}(t)=\frac{1}{2}+\sum_{n=1}^{\infty} \frac{2 \sin (2 n-1) \omega_{0} t}{(2 n-1) \pi}
$$

で表わせる（不連続点の前後で Gibbs の現象が現わ れるが，それが管路系の応答計算に与える影響につい ては別に考察してある7 ので参照されたい)．そして応 答 $p_{0}(t)$ は

$$
\begin{aligned}
p_{0}(t)= & \frac{G(0)}{2}+\sum_{n=1}^{\infty} \frac{2\left|G\left\{j(2 n-1) \omega_{0}\right\}\right|}{(2 n-1) \pi} \\
& \times \sin \left\{(2 n-1) \omega_{0} t+\varphi_{2 n-1}\right\} \\
& \varphi_{2 n-1}=\arg G\left\{j(2 n-1) \omega_{0}\right\}
\end{aligned}
$$

一方，(4) 式を矩形公式（分割幅 $2 \omega_{0}$, 高さ $f\{(2 n-$ 1) $\left.\left.\omega_{0}\right\}, f(\omega)=|G(j \omega)| \sin (\omega t+\varphi) / \pi \omega\right)$ を用いて数值 積分すれば，直ちに (10)式が得られる.したがって， 以上の考察によりステップ応答を矩形パルス列に対す る応答で近似できる根拠を明らかにしたてとになる。

しかし，乙の方法を管路系の応答計算に用いるのは 決して上策とはいえない，なぜなら,被積分関数 $f(\omega)$ は共振点（㧍よび反共振点）付近でその值が急激に変 化し，系が複雑になるほど $f(\omega)$ の変化も複雑にな る. また $\omega$ の増加につれて $f(\omega)$ が 0 亿近づく早さが ゆるやかなため，積分範囲を十分広く取らないと収束 しない場合があり (Katzらの計算例5)には収束してい ない波形む見られる）注意を要する。したがって,積 分法の選定に当たっては上述のごとを考慮に入れる必 要がある，ところが，矩形公式による数值積分法には あとあと精度上の問題があり，精度を上げようとすれ ば他の積分法汇も増して分割数を多くしなければなら ず，その結果計算時間が長くなりすぎるので，広範囲 の積分を精度よく行うには不適である.したがって, 管路系のステップ応答計算には Johnson らの近似法 を用いるより, Simpson の公式などの精度のよい公式 を用いて, 直接 $(4)$ 式を数值積分するほうが望ましい.

\section{参考 文 献}

1) F.T. Brown: The Transient Résponse of Fluid Lines, ASME Trans., Ser D, 84, 547/553 (1962)

2) R. L. Johnson, et al. : Importance of 'Extending Nyquist Servomechanism. Analysis to Include Transient Response, Jour. Aero. Sci., 18,43/49 (1951)

3) W. Kring, et al. : Numerisches Berechnen von Schwingungs und Kriechvorgängen mit der LaplaceTransformation, Ingeniear-Archiv, 44, 335/346 (1975)

4）吉岡活加：周波数特性飞基づく流体回路系の過渡応答計 算法, 日本機械学会講演論文集，784-4，24/27 (1978)

5) S. Katz, et al. : Transient Response of Rectangular Pneumatic Transmission Lines with Blank Chamber Terminations, Fluidics Quart., 8, 85/103 (1976)

6) S. Katz: Transient Response of Fluid Lines by Frequency Response Conversion, ASME Trans., Ser. G, 99, 310/313 (1977)

7）吉岡住加：流体管路におりる任意形状波の線形ひずみ， 流体工学，14，585/593 (1978) 